\title{
Consideration of Contamination Status of Soils within the Vicinity of Automobile Workshops in Warri, Delta State, Nigeria
}

\section{Doris Fovwe Ogeleka ${ }^{1,}$, , Oghenekohwiroro Edjere², Ogechi Okokon-Ndem Nmai ${ }^{3}$, Prisca Ezeogu ${ }^{1}$, Felix Ebodaghe Okieimen ${ }^{4}$}

${ }^{1}$ Department of Chemistry, Federal University of Petroleum Resources, Effurun, Nigeria

${ }^{2}$ Department of Environmental Management and Toxicology, Federal University of Petroleum Resources, Effurun, Nigeria

${ }^{3}$ Department of Production Programming and Quality Control, Warri Refining and Petrochemical Company, Warri, Nigeria

${ }^{4}$ University of Benin, Geo-Environmental and Climate Change Adaptation Research Centre, Benin City, Nigeria

\section{Email address:}

dorysafam@yahoo.com (D. F. Ogeleka)

${ }^{*}$ Corresponding author

\section{To cite this article:}

Doris Fovwe Ogeleka, Oghenekohwiroro Edjere, Ogechi Okokon-Ndem Nmai, Prisca Ezeogu, Felix Ebodaghe Okieimen. Consideration of Contamination Status of Soils within the Vicinity of Automobile Workshops in Warri, Delta State, Nigeria. Science Journal of Chemistry. Vol. 6, No. 4, 2018, pp. 56-65. doi: 10.11648/j.sjc.20180604.14

Received: July 17, 2018; Accepted: August 20, 2018; Published: October 26, 2018

\begin{abstract}
This research appraised the extent of contamination in soils within the vicinity of automobile workshops in Warri, Delta State, Nigeria. This was with the view of ascertaining the effects of the estimated contamination would have on the quality of soils and terrestrial organisms in the impacted soils. The soils were moderate to slightly acidic with a range from $5.42 \pm 0.04$ to $6.41 \pm 0.13$. Zinc contamination in the soils was very severely contaminated (C/P index 0.85$)$, lead had very slight contamination index of 0.11 while copper was moderated polluted with a $\mathrm{C} / \mathrm{P}$ index value of 2.57 . The soils had contamination factor (CF) greater than 6 in all the metals, indicating very high contamination. The degree of contamination was 163.25 , implying very high degree of contamination. The pollution load index value of 5.47 obtained for $n=3$ (metals) showed that the soils had very intense perturbation. Iron being relatively abundant in nature has no $\mathrm{C} / \mathrm{P}$ value as the lists of standards formulated by Department of Petroleum Resources (DPR) excludes iron. Contamination factor obtained for TPH varied from 41.88 to 47.27 . The soils were rated to be excessively contaminated with petroleum hydrocarbons. There was significant variations between the controls and the contaminated soils at levels of $P=.05$. The impacted soils could have detrimental effects on the quality of soils and terrestrial organisms within and around automobile workshops.
\end{abstract}

Keywords: Automobile Workshops, Contamination Factor (CF), Contamination / Pollution Index (C/P), Degree of Contamination (DC), Pollution Load Index (PLI), Petroleum Hydrocarbons, Soils

\section{Introduction}

Humans have invented many means to make life more comfortable and movement from one place to the other easier. Excavating fossil fuels for energy to power vehicles and machines have facilitated the improvement of the quality of life for many people. Unfortunately, many of these inventions have a downside because energy and chemicals needed for such improvements may have adverse impacts on the environment and humans. Manufacturing and application of these products together with the lack of appropriate waste disposal methods / techniques have caused a lot of substances to end up in the environment causing contamination of soil, groundwater, sediments and subsequently the food chain [1].

There is a growing influx of used vehicles ('Tokunbo') into Nigeria on a daily basis since the late 1990s. Even with the recent ban on cars over ten years of manufacturing by the Federal Government, vehicles with a lifespan of more than ten years are still been smuggled into the country and this have increase the numbers of vehicles on the roads, automobile repairs/workshops activities and subsequently the 
amount of pollutants in environmental media (soil, air, water). Since there are no proper regulations on the areas where automobile service workshops should be sited, most automobile mechanics site their workshops in populated residential areas especially in the heart of the cities in most states [2].

Automobile wastes are usually generated after servicing, repairs or maintenance of vehicles, heavy duty machines and other types of engines. The waste which is usually dark brown to black could cause deleterious effects on organisms and the environment when released into recipient bodies, because it contains oxidation products, sediments, water and metallic particles resulting from machinery wears, organic and inorganic chemicals used in oil additives and metals that are present in fuel and transferred to the crankcase during combustion [3].

Considerable quantities of heavy metals such as $\mathrm{Pb}, \mathrm{Zn}$, $\mathrm{Cu}, \mathrm{Cr}, \mathrm{Ni}$, and $\mathrm{Cd}$ are contained in automobile wastes, which are introduced into the oil as a result of wear and tear of the engine. Used oils also contain high percentage of other aromatic and aliphatic hydrocarbons, nitrogen, sulphur compounds and other metals than fresh oils. Automobile waste also include waste oils used for cleaning during servicing, metal scraps, used batteries etc., which are indiscriminately disposed by artisans and subsequently contaminate soils and other environmental media. Due to the low solubility of the spent oils, once discarded, the oils tend to percolated into soil and sediments, and pose threats to underground waters and other recipient systems. The process of evaporation would also release the lighter oily fractions into the atmosphere [4-5].

Soil contamination has been a growing concern, because it can be a source of groundwater (drinking water) contamination since petroleum residuals may be in the soil for years [6]. In Nigeria, it is common practice among automobile mechanics to dispose their waste into water drains and soils [7]. Improper waste disposal practice could cause great damage to soils by creating unsatisfactory conditions for life in the soil, poor aeration, immobilization of soil nutrients, low soil fertility and lowered soil $\mathrm{pH}$ which subsequently result in unsatisfactory seed germination, growth and yield of crop. It could also reduce further usability of the land for development and invariably impair groundwater [8-9].

Waste generation and poor waste management have the potential to pollute the environment since the generated wastes may spill or leak from storage or spent containers. Additionally, improper waste management involving automobile waste may account for environmental pollution within and around these service stations or workshops. The waste oils may affect neighbouring lands when leached into the environment as a result of spill, rains, run-offs and accidental disposal. With respect to this trend, the pollution in environment media (air, water and soils) can be better imagined than experienced. This study, therefore examined an overview of contaminated soils within the vicinity of automobile workshops with a view to determine the extent of pollution, which would provide an impetus on awareness of dangers that lies in indiscriminate disposal of used engine and automobile oils in the environment.

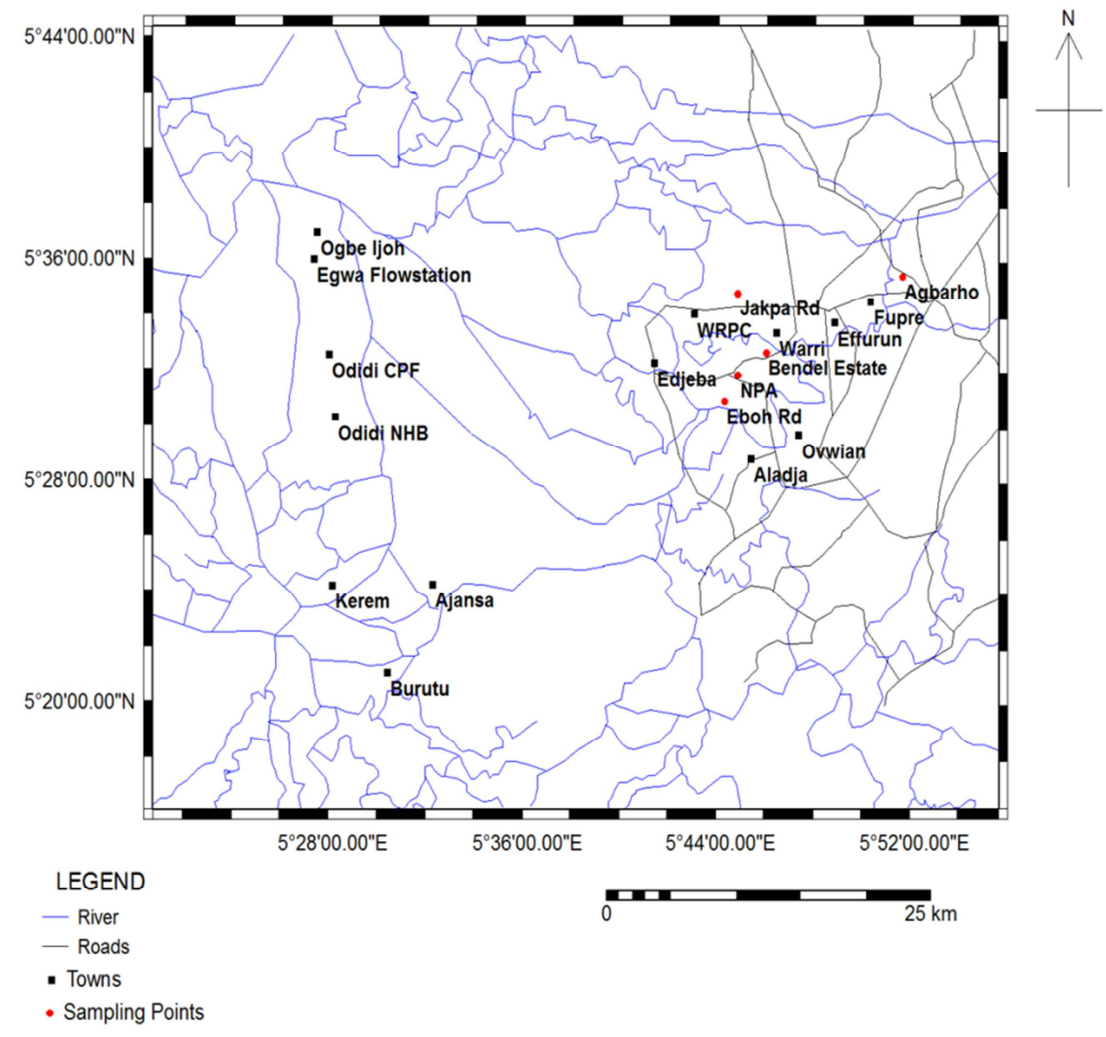

Figure 1. Map of Delta State showing the sampling locations. 


\section{Materials and Method}

\subsection{Study Area}

The study area is Warri and its environs in the Niger Delta area of Delta State, Nigeria. From a small river settlement, Warri has grown to engulf the surrounding towns of Effurun, Ekpan, Enerhen, Edjeba, Ogunu, Jakpa, Ovwian-Aladja and Udu (Figure 1). The area is characterized by tropical equatorial climate with mean annual temperature of $32.8^{\circ} \mathrm{C}$ with rainfall amount of $3000 \mathrm{~mm}$. Rainfall period ranges from January - December. However, double rain maxima between the months of July and September are usually observed. There is a little dry spell in the month of August called August break [10]. Major activities in the area include farming, fishing, trading, burning of wood, fossil fuels, refining of petroleum products, gas flaring, poor / wrong agricultural practices, commercial activities and so on.

\subsection{Collection of Soil Samples}

A total of ninety six (96) soil samples were randomly collected in triplicate at two depths from four major areas of intense mechanic activities which include: Bendel estate, Eboh road, Nigeria Ports Authority (NPA) and Jakpa road. Each of these areas has a minimum of four to five workshops clustered in empty plots of lands at different sites off the major roads in the respective locations. Background (control) samples were collected from an area in Agbaroh, Delta State, where there was no automobile activity (Table 1). In each case, soil samples were taken from the surface $(0-15 \mathrm{~cm})$ and first sub-surface $(15-30 \mathrm{~cm})$ and would subsequently be referred to as topsoil and subsoil respectively. After collection, objects such as dead weed, stems, leaves, sticks and stones were carefully removed and the soil samples were transferred into labeled containers. In the laboratory, the soils were air dried, gently crushed and sieved through a 2-mm sieve. These were kept for further treatment and analysis of the different components needed for the study. The sampling areas are geo-referenced as in Table 1.

Table 1. Sampling points and geographical coordinates.

\begin{tabular}{|c|c|c|}
\hline Sampling Location & Latitude & Longitude \\
\hline Background (control) & $\mathrm{N} 5^{0} 35^{\prime} 21.67^{\prime \prime}$ & E $5^{0} 51^{\prime} 34.17^{\prime \prime}$ \\
\hline Bendel Estate & N $5^{0} 32^{\prime} 32.76^{\prime \prime}$ & E $5^{0} 45^{\prime} 58.53^{\prime \prime}$ \\
\hline NPA, Warri & N $5^{0} 32^{\prime} 18.26^{\prime \prime}$ & E $5^{0} 44^{\prime} 48.85^{\prime}$ \\
\hline Jakpa Road & N $5^{0} 33^{\prime} 51.75^{\prime \prime}$ & E $5^{0} 45^{\prime} 16.46^{\prime}$ \\
\hline Eboh Road & N $5^{0} 31^{\prime} 37.24$ ', & E $5^{0} 45^{\prime} 01.16^{\prime \prime}$ \\
\hline
\end{tabular}

\subsection{Methods for Soil Quality Parameters}

The properties of the soil samples were determined by standard methods as detailed in Table 2.

Table 2. Methods for soil quality parameters.

\begin{tabular}{ll}
\hline Parameters & Analytical Methods \\
\hline $\mathrm{pH}$ & $\mathrm{pH},\left(\mathrm{APHA} 4500 \mathrm{H}^{+}\right)$Folsom et al, [11] \\
Total organic content $(\%)$ & Walkey and Black, [12] \\
Exchangeable bases $(\mathrm{Ca}, \mathrm{Mg}, \mathrm{Na}$ and $\mathrm{K})$ & Extraction and Atomic Absorption Spectrophotometer \\
Total Petroleum Hydrocarbon (TPH) & Extraction and Gas chromatography (USEPA \#418.1 (USEPA, [13] \\
Soil texture & IITA, [14] \\
Soil particle size & IITA, [14] \\
Heavy metals & Atomic Adsorption Spectrometer (AAS) (Shimazu 6701 F model) \\
\hline
\end{tabular}

\subsection{Assessment of Contamination Status}

The contamination or pollution status of soil and/or sediment could be estimated using various indices such as contamination/pollution index $(\mathrm{C} / \mathrm{P})$, concentration factor (CF), degree of contamination (DC), pollution load index (PLI) etc.

\section{(i) Contamination / Pollution index}

Pollution index was estimated using standard employed for interpreting soil contamination/pollution for each parameter of interest [15]. The contamination/pollution index $\mathrm{C} / \mathrm{P}$ represents the inorganic and organic content effectively measured in soil and the reference value of the contamination obtained using the standard table as stipulated by the Department of Petroleum Resources (DPR) for the maximum allowable concentration of the contaminant in the media [16]. The Dutch target and intervention values could also be used, however, since the soils are indigenous to Nigeria, the DPR specified values were employed. If the $\mathrm{C} / \mathrm{P}$ index value is greater than unity (1), it defines a pollution range and when lower than unity the contamination range. It could be calculated using the formula given below:

$$
\mathrm{C} / \mathrm{P}=\frac{\text { actual measurement of contaminant concentration in medium }}{\text { Target values from reference table }}
$$

Indexes were calculated using the target standard values in Table 3 and the ratings from Table 4 was used to adjudge the pollution index for the study area.

Table 3. Target and intervention values for organics and inorganics components in soil.

\begin{tabular}{lll}
\hline Metals & Target values $(\mathbf{m g} / \mathbf{k g})$ & Intervention values $(\mathbf{m g} / \mathbf{k g})$ \\
\hline Barium & 200 & 5000 \\
Cadmium & 0.8 & 17 \\
Chromium & 100 & 380 \\
Copper & 36 & 190 \\
Mercury & 0.3 & 10 \\
Lead & 85 & 530 \\
Nickel & 35 & 210 \\
Zinc & 140 & 720 \\
Cobalt & 20 & 240 \\
Mineral oils & 50 & 5000 \\
\hline
\end{tabular}

Source: DPR, [16] 
Table 4. Significance of intervals of contamination/pollution index $(C / P)$ values.

\begin{tabular}{lll}
\hline $\mathbf{C} / \mathbf{P}$ & Significance & Symbols \\
\hline$<0.1$ & Very slight contamination & Vsl \\
$0.10-0.25$ & Slight contamination & $\mathrm{S} 1$ \\
$0.26-0.5$ & Moderate contamination & Mo \\
$0.51-0.75$ & Severe contamination & $\mathrm{Stl}$ \\
$0.76-1.0$ & Very severe contamination & Vstl \\
$1.1-2.0$ & Slight pollution & $\mathrm{Sp}$ \\
$2.1-4.0$ & Moderate pollution & $\mathrm{Mp}$ \\
$4.1-8.0$ & Severe pollution & $\mathrm{Stp}$ \\
$8.1-16.0$ & Very severe pollution & Vstp \\
$>16$ & Excessive pollution & Ep \\
\hline
\end{tabular}

Source: Lacatusu, [15]

\section{(ii) Contamination factor (CF)}

Contamination factor (CF) is also called single pollution index (PI). Contamination factor is the quotient obtained by dividing the concentration of metals in the contaminated medium by the reference (background or control) area. The contamination factor can be calculated through the following formula as suggested by Harikumar et al., 17].

$$
\mathrm{CF}=\frac{M_{\text {contam }}}{M_{\text {background }}}
$$

In the above equation, $\mathrm{Mc}$ is the concentration of metals in the contaminated or target area, and $\mathrm{M}_{\mathrm{b}}$ is the metals concentration of the reference area. Contamination factor (CF) gives an indication of the elevation of the levels of contaminants in the test medium in comparison with the background or control samples. $\mathrm{CF}$ is categorized as tabulated in Table 5.

Table 5. Classification of contamination factor.

\begin{tabular}{ll}
\hline Contamination factor & Classification \\
\hline $\mathrm{CF}<1$ & Low \\
$1 \leq \mathrm{CF}<3$ & Moderate \\
$3 \leq \mathrm{CF}<6$ & Considerable \\
$\mathrm{CF} \geq 6$ & Very high \\
\hline
\end{tabular}

Source: Hakanson, [18]; Okieimen, [19]

\section{(iii) Degree of contamination index (DC)}

The degree of contamination (DC) of one determined area is the sum of all contamination factors of the studied parameters. DC is obtained using the relationship in equation 3.

$$
\mathrm{DC}=\sum \mathrm{CF}
$$

An area could be classified according to DC values given in Table 6.

Table 6. Classification of degree of contamination.

\begin{tabular}{ll}
\hline Degree of Contamination & Classification \\
\hline $\mathrm{DC}<8$ & Low \\
$8 \leq \mathrm{DC}<16$ & Moderate \\
$16 \leq \mathrm{DC}<32$ & Considerable \\
$\mathrm{DC} \geq 32$ & Very high \\
\hline
\end{tabular}

Source: Hakanson, [18]; Okieimen, [19]

\section{(iv) Pollution load index}

Results of contamination factor (CF) are mostly associated with single pollution load, while their n-root is used for integrated pollution load index. Pollution load index (PLI) is a simple statistical technique used to determine elemental contents in the medium beyond the reference concentration and it provides comprehensive information about the metals toxicity in respective samples [20-21]. Pollution load index can be determined through the following formula:

$$
\mathrm{PLI}=\sqrt[n]{\pi \mathrm{CF}}
$$

Where PLI represents the pollution load index, CF is the contamination factor, and $\mathrm{n}$ is the number of elements (contaminants). That is the $n$-root of the product of CF. PLI provides a simple means of assessing the quality of an environmental medium. Table 7 showed the classification for PLI. The PLI $>1$ indicates polluted, while PLI $<1$ indicates no pollution.

Table 7. Classification of pollution load index (PLI).

\begin{tabular}{ll}
\hline Degree of Contamination & Classification \\
\hline PLI $=0$ & Perfect situation \\
PLI $=1$ & Baseline levels \\
PLI $>1$ & Perturbation or pollution of the medium \\
\hline
\end{tabular}

Source: Hakanson, [18]; Okieimen, [19]

\subsection{Statistical Analysis}

All experiments were conducted in triplicate and used for the calculation of the means for organic and inorganic components of the soils. The statistical test was carried out to determine the level of significance at $\mathrm{P}<.05$ using analysis of variance (ANOVA). Line graphs were used to illustrate the means of the various measurement variables.

\section{Results}

The results for the physico-chemical parameters, heavy metals and organics obtained from the contaminated soils within the vicinity of automobile workshops in Bendel estate, NPA, Jakpa road, Eboh road and Agbarho (control) are presented in Tables $8-13$ and Figures 2 - 3 .

The particle size distribution of soil samples are shown in Table 8 . The soil was principally loamy sand with sand constituting more than $65 \%$ of the inorganic mineral fragment. Soil texture, which is a physical property of the soil, refers to the relative percentages of sand, silt, and clay. Where clay is the smallest soil particle, sand is the largest soil particle and silt is an intermediate sized soil particle. The texture of the soil determines the permeability of the soils with respect to mobility of substance in the soil. 
Table 8. Mean particle size distribution of the soils.

\begin{tabular}{|c|c|c|c|c|}
\hline Sample Location & $\%$ Sand & $\%$ Silt & \% Clay & Texture \\
\hline Control (topsoil - 0-15 cm) & 93.80 & 1.10 & 5.10 & Sandy \\
\hline Control (subsoil - 15-30 cm) & 91.80 & 2.10 & 6.10 & Sandy \\
\hline Bendel Estate (topsoil - 0-15 cm) & 84.80 & 6.30 & 8.90 & Sandy loam \\
\hline NPA (topsoil - 0-15 cm) & 79.80 & 13.10 & 7.10 & Loamy Sandy \\
\hline NPA (subsoil - 15-30 cm) & 79.80 & 13.10 & 7.10 & Loamy Sandy \\
\hline Jakpa (topsoil - 0-15 cm) & 81.80 & 9.10 & 9.10 & Loamy Sandy \\
\hline Eboh (topsoil - 0-15 cm) & 67.80 & 18.10 & 14.10 & Sandy loamy \\
\hline Eboh (subsoil - 15-30 cm) & 69.80 & 10.10 & 20.10 & Sandy loamy \\
\hline
\end{tabular}

The $\mathrm{pH}$ values for soils in the study area were moderate to slightly acidic with range from $5.42 \pm 0.04$ in NPA, $0-15 \mathrm{~cm}$ to $6.41 \pm 0.13$ in the control, $15-30 \mathrm{~cm}$ (Table 9 and Figure 2). The $\mathrm{pH}$ range for typical soils is presented in Table 10.

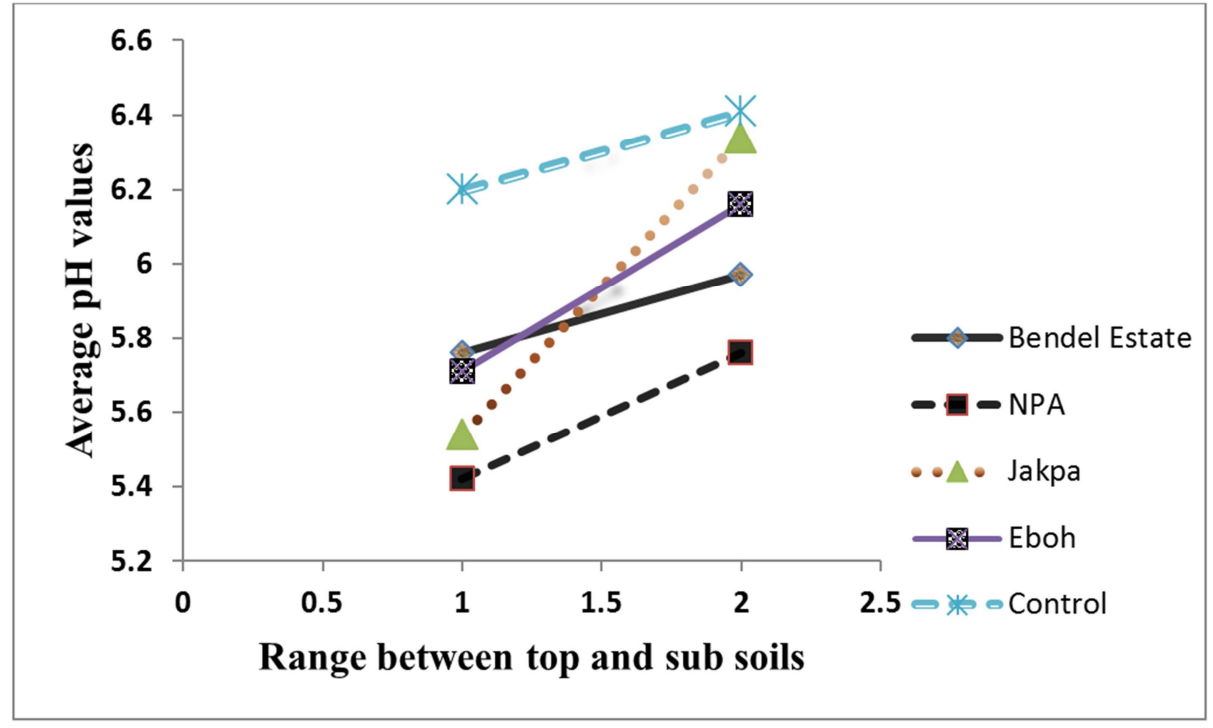

Figure 2. Mean pH of soils in the study area.

Table 9. Mean $\pm S D$ of soil $p H$ in the study area.

\begin{tabular}{lll}
\hline Sample Location & Topsoil $(\mathbf{0 - 1 5 c m})$ & Subsoil $(\mathbf{0 - 1 5 c m})$ \\
\hline Control & $6.20 \pm 0.10$ & $6.41 \pm 0.13$ \\
Bendel Estate & $5.76 \pm 0.13$ & $5.97 \pm 0.03$ \\
NPA & $5.42 \pm 0.04$ & $5.76 \pm 0.03$ \\
Jakpa & $5.54 \pm 0.03$ & $6.34 \pm 0.01$ \\
Eboh & $5.71 \pm 0.11$ & $6.16 \pm 0.04$ \\
\hline
\end{tabular}

The results for the mean exchangeable acidity, bases and effective cation exchange capacity (ECEC) in $\mathrm{cmol}(+) / \mathrm{kg}$ are presented in Table 11. The effective cation exchange capacity (ECEC), which is the sum of exchangeable bases $\left(\mathrm{Ca}^{2+}\right.$, $\left.\mathrm{Mg}^{2+}, \mathrm{Na}^{+}, \mathrm{K}^{+}\right)$and exchange acidity $\left(\mathrm{Al}^{3+}+\mathrm{H}^{+}\right)$are expressed in $\mathrm{cmol} / \mathrm{kg}$. In soils, the desired range is between 5 $-25 \mathrm{cmol} / \mathrm{kg}$. Where ECEC is less than 5, is indicative of low soil fertility. The concentrations from this study indicated that the soils were moderate in nutrient.

Table 10. $p H$ range for typical soils.

\begin{tabular}{|c|c|c|c|c|c|}
\hline$<5.0$ & 5.5 & 6.0 & $6.5-7.5$ & $7.5-8.5$ & $>8.5$ \\
\hline Strongly acid & Moderately acid & Slightly acid & Neutral & Moderately alkaline & Strongly alkaline \\
\hline
\end{tabular}

Table 11. Mean exchangeable acidity, bases and ECEC in $\mathrm{cmol}(+) / \mathrm{kg}$.

\begin{tabular}{llll}
\hline Sample Location & Exchangeable acids & Exchangeable bases & Total ECEC \\
\hline Control & $1.70 \pm 0.03$ & $28.28 \pm 0.10$ & $29.98 \pm 0.07$ \\
Bendel & $1.44 \pm 0.02$ & $24.76 \pm 0.16$ & $26.20 \pm 0.12$ \\
NPA & $1.28 \pm 0.06$ & $21.98 \pm 0.36$ & $23.26 \pm 0.13$ \\
Jakpa & $1.84 \pm 0.04$ & $24.06 \pm 0.20$ & $25.90 \pm 0.18$ \\
Eboh & $1.04 \pm 0.02$ & $26.43 \pm 0.09$ & $27.47 \pm 0.09$ \\
\hline
\end{tabular}

ECEC $=$ Total sum of exchangeable acid + Total sum of exchangeable base 
The data on organic carbon content ranged from $0.12 \pm$ 0.01 to $3.41 \pm 0.08 \%$ (Table 12 ). Total organic carbon (TOC) is a measure of the carbon contained within soil organic matter. Organic matter is commonly and incorrectly used to describe the same soil fraction as total organic carbon. Organic matter is different from total organic carbon because it includes all the elements (hydrogen, oxygen, nitrogen, etc.) that are components of organic compounds, not only carbon. All soils in the study area fall under low to medium content category of organic carbon. The highest TOC content (3.41 \pm $0.08 \%$ ) was observed in Jakpa (top soil $-0-15 \mathrm{~cm}$ ) while the lowest $(0.12 \pm 0.01 \%)$ was obtained in the control (bottom soil $-15-30 \mathrm{~cm})$. The surface horizons of all the profiles were higher in organic matter than sub-surface horizons. A general trend of decreasing organic carbon with depth was observed in all the samples except NPA. The TOC content increased from the topsoil to bottom soils, this increasing trend of TOC might be attributed to the high concentration of the spilled oil on the top soil as compared to the bottom soil, except for NPA where the bottom soil has a higher TOC compared to the bottom. This showed that spilled oil had settled deeply into the soil since it was an old automobile workshop that the soil had been impacted compared to the other mechanic workshops in Jakpa road, Bendel Estate and Eboh road.
Table 12. Mean concentration of total organic matter and carbon (TOM and TOC).

\begin{tabular}{lll}
\hline Samples & TOM \% & TOC \% \\
\hline Control (topsoil $-0-15 \mathrm{~cm}$ ) & $0.67 \pm 0.05$ & $0.39 \pm 0.03$ \\
Control (subsoil $-15-30 \mathrm{~cm}$ ) & $0.21 \pm 0.03$ & $0.12 \pm 0.01$ \\
Bendel Estate (topsoil $-0-15 \mathrm{~cm}$ ) & $5.48 \pm 0.07$ & $3.18 \pm 0.05$ \\
Bendel Estate (subsoil $-15-30 \mathrm{~cm}$ ) & $4.48 \pm 0.04$ & $2.60 \pm 0.06$ \\
NPA (topsoil $-0-15 \mathrm{~cm}$ ) & $5.48 \pm 0.10$ & $3.18 \pm 0.10$ \\
NPA (subsoil $-15-30 \mathrm{~cm}$ ) & $5.69 \pm 0.12$ & $3.30 \pm 0.06$ \\
Jakpa (topsoil $-0-15 \mathrm{~cm}$ ) & $5.88 \pm 0.11$ & $3.41 \pm 0.08$ \\
Jakpa (subsoil - $15-30 \mathrm{~cm}$ ) & $1.60 \pm 0.02$ & $0.93 \pm 0.01$ \\
Eboh (topsoil $-0-15 \mathrm{~cm}$ ) & $2.53 \pm 0.03$ & $1.43 \pm 0.02$ \\
Eboh (subsoil $-15-30 \mathrm{~cm}$ ) & $2.34 \pm 0.04$ & $1.36 \pm 0.02$ \\
\hline
\end{tabular}

The mean results of the metals analysed in the study are shown in Table 13. The results showed that zinc level ranged from $17.6 \pm 0.11 \mathrm{mg} / \mathrm{kg}$ in the control - topsoil to $128.1 \pm 6.0$ $\mathrm{mg} / \mathrm{kg}$ in NPA topsoil. Iron concentrations in the subsoil for the control recorded $106.0 \pm 3.2 \mathrm{mg} / \mathrm{kg}$ while the highest 352 $\pm 6.9 \mathrm{mg} / \mathrm{kg}$ was reported in Eboh topsoil. Similarly, $0.052 \pm$ $0.06 \mathrm{mg} / \mathrm{kg}$ (control - topsoil) was reported for lead while the maximum value of $13.6 \pm 0.98 \mathrm{mg} / \mathrm{kg}$ was recorded in Eboh subsoil. Copper concentration varied from $12.83 \pm 0.04$ $\mathrm{mg} / \mathrm{kg}$ (control - topsoil) to $113 \pm 0.54 \mathrm{mg} / \mathrm{kg}$ (NPA topsoil). The values of all metals determined within the intervention (tolerable) values recommended by Department of Petroleum Resources (DPR) [16].

Table 13. Mean concentrations of heavy metals in soils.

\begin{tabular}{|c|c|c|c|c|c|c|}
\hline Parameter & $\begin{array}{l}\text { DPR target } \\
\text { value }\end{array}$ & $\begin{array}{l}\text { DPR Intervention } \\
\text { value }\end{array}$ & $\begin{array}{l}\text { Control } \\
\text { (topsoil - 0-15 cm }\end{array}$ & $\begin{array}{l}\text { Control } \\
(\text { subsoil - 15-30 cm }\end{array}$ & $\begin{array}{l}\text { Bendel Estate } \\
(\text { topsoil - 0-15 cm) }\end{array}$ & $\begin{array}{l}\text { Bendel Estate (subsoil - } \\
15-30 \mathrm{~cm} \text { ) }\end{array}$ \\
\hline $\mathrm{Fe}$ & N/A & N/A & $113.2 \pm 3.7$ & $106.0 \pm 3.2$ & $323 \pm 5.2$ & $261 \pm 32$ \\
\hline $\mathrm{Zn}$ & 140 & 720 & $17.6 \pm 0.11$ & $17.6 \pm 0.09$ & $121.7 \pm 2.9$ & $110.4 \pm 9.4$ \\
\hline $\mathrm{Pb}$ & 85 & 530 & $0.072 \pm 0.01$ & $0.052 \pm 0.06$ & $10.2 \pm 0.64$ & $6.32 \pm 0.44$ \\
\hline $\mathrm{Cu}$ & 36 & 190 & $12.83 \pm 0.04$ & $17.1 \pm 0.02$ & $108 \pm 0.99$ & $93 \pm 2.8$ \\
\hline
\end{tabular}

Table 13. Continue.

\begin{tabular}{|c|c|c|c|c|c|c|}
\hline Parameter & $\begin{array}{l}\text { NPA } \\
\text { (topsoil - 0-15 cm }\end{array}$ & $\begin{array}{l}\text { NPA } \\
\text { (subsoil }-15-30 \mathrm{~cm}\end{array}$ & $\begin{array}{l}\text { Jakpa } \\
\text { (topsoil - 0-15 cm }\end{array}$ & $\begin{array}{l}\text { Jakpa } \\
\text { (subsoil - 15-30 cm } \\
\end{array}$ & $\begin{array}{l}\text { Eboh } \\
\text { (topsoil - 0-15 cm }\end{array}$ & $\begin{array}{l}\text { Eboh } \\
\text { (subsoil - 15-30 cm }\end{array}$ \\
\hline $\mathrm{Fe}$ & $317.3 \pm 7.9$ & $248.6 \pm 4.9$ & $308.4 \pm 3.4$ & $217 \pm 9.3$ & $352 \pm 6.9$ & $219 \pm 3.1$ \\
\hline $\mathrm{Pb}$ & $9.73 \pm 0.34$ & $5.28 \pm 0.39$ & $11.07 \pm 0.44$ & $8.16 \pm 0.76$ & $13.6 \pm 0.98$ & $10.2 \pm 0.54$ \\
\hline $\mathrm{Cu}$ & $113 \pm 0.54$ & $97 \pm 3.2$ & $86.7 \pm 2.7$ & $57.3 \pm 1.3$ & $102.6 \pm 3.5$ & $81.4 \pm 3.0$ \\
\hline
\end{tabular}

SD: standard deviation; N/A - Not available

The contamination/pollution $\mathrm{C} / \mathrm{P}$ index ranged from less than unity to greater than unity for all the metals, indicating a rating of very slight contamination to moderate contamination of the soils with heavy metals (Table 4). Zinc contamination in the soils was very severely contaminated (C/P index 0.85$)$, lead had very slight contamination index of 0.11 while copper was moderated polluted with a $\mathrm{C} / \mathrm{P}$ index value of 2.57 . The soils had contamination factor $(\mathrm{CF})$ greater than 6 in all the metals, indicating very high contamination (Table 5). Using the rating as stipulated in
Table 6, the degree of contamination was greater than 32 , a value of 163.25 was obtained, implying very high degree of contamination. The pollution load index value of 5.47 obtained for a n-root (3) showed that the soils had very intense perturbation (Table 7). Fe being relatively abundant in nature has no $\mathrm{C} / \mathrm{P}$ value as the lists of standards formulated by Department of Petroleum Resources excludes Fe (DPR, 2002) [16], hence the total metal load was evaluated using $\mathrm{Zn}, \mathrm{Pb}$ and $\mathrm{Cu}$. 
Table 14. Anthropogenic contamination status of heavy metals in soils.

\begin{tabular}{lllllll}
\hline Parameters & Pseudo-total metals levels $(\mathbf{m g} / \mathbf{k g})$ & Background levels & $\mathbf{C F}$ & $\mathbf{C} / \mathbf{P}$ & DC $=\sum \mathbf{C F}$ & PLI $=\sqrt[n]{\boldsymbol{\pi C F}}$ \\
\hline $\mathrm{Zn}$ & $118.63 \pm 1.02$ & $17.6 \pm 0.10$ & 6.74 & 0.85 & & \\
$\mathrm{~Pb}$ & $9.32 \pm 0.22$ & $0.062 \pm 0.03$ & 150.32 & 0.11 & 163.25 & 5.47 \\
$\mathrm{Cu}$ & $92.38 \pm 0.74$ & $14.92 \pm 0.04$ & 6.19 & 2.57 & & \\
\hline
\end{tabular}

The results of total metals in Table 15, indicated that there was no spatial variation between the different contaminated sites for the total metal load, however, there was significant difference between the contaminated soils and the background (reference) sample at levels of $P=.05$ implying that the controls were typically free of heavy metal contaminations.

Table 15. Spatial variation of total metals in soils.

\begin{tabular}{lllll}
\hline Parameter & Control & Bendel Estate & NPA & Jakpa \\
\hline Total metal $(\mathrm{Zn}+\mathrm{Pb}+\mathrm{Cu})$ & $65.25 \pm 0.1$ & $449.62 \pm 3.2$ & $471.11 \pm 3.9$ & $401.13 \pm 2.9$ \\
$\mathrm{CF}$ & 1 & 6.89 & 7.22 & 6.15 \\
\hline
\end{tabular}

The results of the analysis as shown in Figure 3 illustrates the level of TPH at the two depths - (topsoil $-0-15 \mathrm{~cm})$ and (subsoil $-15-30 \mathrm{~cm}$ ) of the contaminated soil samples. In Bendel Estate, the mean TPH concentration decreases as depth increased. The highest TPH concentration was recorded at the depth of $0-15 \mathrm{~cm}$ with a mean TPH value
$1317 \pm 2.5 \mathrm{mg} / \mathrm{kg}$ (Figure 3). Similar trend was observed in the other sampled locations. The TPH values obtained from all the sampled stations except the control exceeded the recommended Department of Petroleum Resources (DPR) target limit of $50 \mathrm{mg} / \mathrm{kg}$ but were however within the DPR Intervention value of $5000 \mathrm{mg} / \mathrm{kg}$.

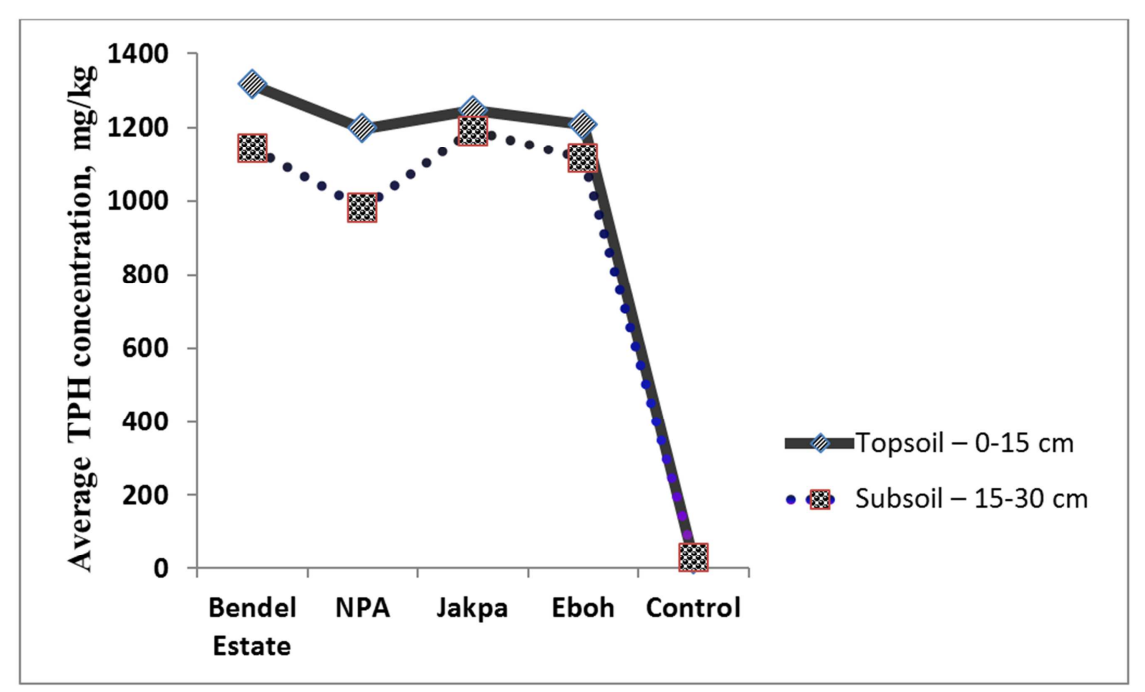

Figure 3. Mean \pm SE of TPH concentrations in soils.

The soils from the contaminated site can be categorized as very highly contaminated by TPH. CF values obtained varied from 41.88 in NPA to 47.27 in Bendel Estate. The results for $\mathrm{C} / \mathrm{P}$ varied from 21.78 in NPA to 24.58 in Bendel estate. Since, the $\mathrm{C} / \mathrm{P}$ index were greater than 16 , the soils were rated to be excessively contaminated with petroleum hydrocarbons (Tables 3, 4, 16). The controls were typically free of hydrocarbon pollution, the very low concentrations reported could be due to biogenic components in the soils. There was significant variations between the controls and the contaminated soils at levels of $P=.05$.

Table 16. Anthropogenic contamination status of TPH in soils.

\begin{tabular}{lllll}
\hline Parameter & Control & Bendel Estate & NPA & Jakpa \\
\hline TPH & $26 \pm 0.09$ & $1229 \pm 12.4$ & $1089 \pm 10.2$ & $1220 \pm 11.9$ \\
CF & 1 & 47.27 & 41.88 & 46.92 \\
C/P & 0.52 & 24.58 & 21.78 & 24.40 \\
\hline
\end{tabular}

\section{Discussion}

Automobile waste oils dumped indiscriminately in service and maintenance workshops can invariably influence the quality and terrestrial lives in the soil. In this research, the soils were moderate to slightly acidic. The low $\mathrm{pH}$ levels could be attributed to the breakdown of organic matter (automobile spent oils) releasing hydrogen. Similarly, the acidity could have been influenced by other service activities including dumping / disposal of waste batteries containing acids. Also another possible influence in the region with 
respect to low $\mathrm{pH}$ could be as a result of acid-rain caused by long-term gas flaring from refinery in close proximity to some of the sampled locations [22-24].

Plant growth and most soil processes, including nutrient availability and microbial activity, are favoured by a soil $\mathrm{pH}$ range of 5.5-8. Acid soil, particularly in the subsurface, will also restrict root access to water and nutrients. The lower the $\mathrm{CEC}$ of a soil, the faster the soil $\mathrm{pH}$ will decrease with time. In very acid soils, all the major plant nutrients (nitrogen, phosphorus, potassium, sulphur, calcium, manganese and also the trace element molybdenum) may be unavailable, or only available in insufficient quantities. Plants can show deficiency symptoms despite adequate fertiliser application. If the topsoil $\mathrm{pH}$ is below 5.5, liming would restore the soil fertility. Liming is necessary if the subsurface $\mathrm{pH}$ is below 4.8, whether or not the topsoil is acidic. Liming soils to higher than $\mathrm{pH} 5\left(\mathrm{CaCl}_{2}\right)$ will maintain exchangeable plant nutrient cations [25-26].

Total organic carbon influences many soil characteristics including colour, nutrient holding capacity (cation and anion exchange capacity), nutrient turnover and stability, which in turn influence water relations, aeration and workability. By providing a food source for micro-organisms, organic carbon can help improve soil stability by micro-organisms binding soil particles together into aggregates. Bacteria excretions, root exudates, fungal hyphae and plant roots can all contribute to better soil structure.

The metal content of mechanic waste is also very important, because many of these metals at certain concentrations are potentially very dangerous to living organisms and plants in the soil [27]. Automobile waste contains high concentrations of lead $(\mathrm{Pb})$, zinc $(\mathrm{Zn})$, cadmium $(\mathrm{Cd})$, barium $(\mathrm{Ba})$, magnesium $(\mathrm{Mg})$, and lower concentrations of Iron $(\mathrm{Fe})$, sodium $(\mathrm{Na})$, copper $(\mathrm{Cu})$, aluminum $(\mathrm{Al})$, chromium $(\mathrm{Cr})$, manganese $(\mathrm{Mn})$, potassium $(\mathrm{K})$ and nickel $(\mathrm{Ni})$. The concentration of metals in oil increase with motor operating time and the amount is dependent on fuel type and the mechanical condition of the engine [28-29].

Similarly, the abundance of some of these metals might be due to their relative abundance in soil or the anthropogenic source from the metal junkyard found in many of the auto mechanic site. Used oils that sink into the ground as leachates contain high proportions of these metals. $\mathrm{Cu}, \mathrm{Pb}$ and $\mathrm{Sb}$ from babbit metal bushings, $\mathrm{Cr}$ and Mo from piston rings and seals, $\mathrm{Cu}$ and $\mathrm{Sn}$ from metal bearing wears, Ni and Fe from crankshafts wear and engine body damage, which may leach into the soil during maintenance, disposal or spills [2].

Most of the used motor oils in automobile workshops are combusted and this operation produces large quantities of heavy metal emissions. The emitted particles and residue products are ranked to be among the most toxic in comparison with other environmental particles. The sandy formation was porous and permeable, which implied that heavy metals and organics from the waste oils could migrate easily into the unconfined shallow aquifer to contaminate the groundwater system.

The enrichment of the soil with lead may be attributed the various human activities ongoing around the mechanic workshops. Some of the concentration of lead in the soil could be from automobile exhaust fumes, decay of abandoned dry cell electric batteries and runoff of wastes. [30]. In the case of mechanic waste, the presence of lead can diminish hydrocarbon biodegradation [31]. The concentrations reported for copper and zinc could be from decomposition of electrical materials, roofing sheets, alloys, etc. At low concentrations, some of these heavy metals are essential micronutrients for plants, but at high concentrations they could cause metabolic disorders and growth inhibition. Iron and other metal toxicity may arise at certain high enough concentrations [7].

High heavy metals load in the soil could cause significant environmental damage to terrestrial organisms, plants and soil health. Similarly, atmospheric depositions could cause its bioaccumulation in plant via uptake from the soil and eventual entry into the food chain $[29,32,33]$. These results agreed with the findings of some authors namely Oguntimehin and Ipinmorotie, [2], Adedokun and Ataga, [33], Vwioko et al., [34] and Bello et al., [35].

The TPH concentrations in the topsoils from the four locations were higher than the bottom soils. This indicated that the effect of contamination from disposed / spilled automobile waste on the soil increases the TPH level present in the soil. Thus we can deduce that the spent / used oil was gradually sipping into the bottom soil. However, the TPH values obtained in this study exceeded the minimum 50 $\mathrm{mg} / \mathrm{kg}$ recommended by Department of Petroleum Resources (DPR) in all the locations. TPH concentrations between 100 to $500 \mathrm{mg} / \mathrm{kg}$ have been reported by some authors Adeniyi and Afolabi, [36] and Martins and Peixoto, [37].

Total petroleum hydrocarbon (TPH) contaminated soil poses environmental hazards. Similarly, used oils in soil can induce a drastic change in the microbial communities. These changes can affect the biological cycles in the soil, inhibits plant development and hence increase the metal content of surviving plants. The oil displaces air and water leading to anaerobic condition [6]. The presence of spent oil in the soil decreases the water holding capacity, aeration and reduces the nitrogen, phosphorous and potassium content of the soil due to the high level of heavy metals contained in the oil especially used lubricating oil [34]. Odjegba and Sadiq, [8], reported low yield and decreased growth of plant grown in spent lubricant oil contaminated soil. It has also been shown that there are marked changes in properties when soils are contaminated with hydrocarbon and this could affect the physical, chemical and microbiological properties of the soil [38-40].

\section{Conclusion}

The extent of pollution in soils within the vicinity of automobile workshops was estimated for organics and inorganics in this research. Organic matter is considered to 
lower soil $\mathrm{pH}$ by releasing hydrogen ions that are associated with the organic anions, a condition which is not favourable for the survival of plants, could have been influenced in this study by spent automobile oils, dumping / disposal of waste batteries containing acids and long-term gas flaring from refinery in close proximity to automobile workshops. Terrestrial growth and most soil processes, including nutrient availability and microbial activity could be impaired as a result of acid soils and these soils are susceptible to erosion and compaction. In addition, heavy metals load in the soil could adversely affect environmental media resulting in bioaccumulation of metal species along the food chain, which could in turn damage terrestrial flora and fauna, alter soil quality and impair human health. Petroleum contaminated soil poses environmental hazards. Oil levels in the soil decreases the water holding capacity, aeration and reduces the nitrogen, phosphorous and potassium content of the soil due to the high level of heavy metals contained in the oil. Thus, as a result of spent oils in soils, microbial metabolic activities will be impaired, plant growth and development inhibited while the metal load in tolerant species would increase. The results obtained from this study revealed the improper disposed of used engine oil by mechanics on the soil and this could be harmful to terrestrial lives, soils and subsequently humans.

\section{References}

[1] A. B. Busari, S. S. Kukal, A. Kaur, R. Bhatt, A. A. Dulazi. Conservation tillage impacts on soil, crop and the environment. International Soil and Water Conservation Research. 3 (2015) 119-129.

[2] I. Oguntimehin, K. Ipinmorotie. Profile of heavy metals from automobile workshops in Akure, Nigeria. Journal of Environmental Science and Technology. 1 (2008) 19-26.

[3] EEA (European Environment Agency). Progress in management of contaminated sites (CSI 015).. Assessment Published July 2005; Kongen, Ytorv, 6 DK-1050, Denmark (2007).

[4] A. S. Abdulkareem, A. S. Afolabi, S. O. Ahanonu, T. Mokrani. Effect of treatment methods on used lubricating oil for recycling purposes. Energy sources, Part A: Recovery. Utilization and Environmental Effects. 6 (2014) 966-973.

[5] G. O. Anoliefo, D. E. Vwioko. Tolerance of Chromolema odorota (L.) K and R. grown in soil contaminated with spent lubricant oil. Journal of Crop Bioscience. 1 (2001) 20-24.

[6] J. Kayode, A. A. Oyedeji, O. Olowoyo. Evaluation of the effect of pollution with spent lubricant oil on the physical and chemical properties of soil. Pacific Journal of Science and Technology. 10(1) (2009) 387-39.

[7] B. O. Okonokhua, B. Ikhajiagbe, G. O. Anoliefo, T. O. Emede. The effects of mechanic waste on soil properties and growth of maize (Zea mays L.). Journal of Applied Science and Environmental Management. 11(3) (2007) 147-152.

[8] V. J. Odjegba, A. O. Sadiq. The environment: Effect of mechanic waste on the growth parameters. Chlorophyll and protein levels of Amaranthus hybridus L. J. Environmental Science. 22(1) (2002) 23-28.

[9] S. C. Ugoh, L. C. Moneke. Isolation of bacteria from engine oil contaminated soils in auto mechanic workshops in Gwagwalada, Abuja, FCT - Nigeria. Academia Arena. 3(5) (2011) 28-33

[10] V. N. Ojeh. Thermal comfort characteristics in Warri and environs, Delta State, Nigeria, an unpublished M. Sc Dissertation in the Department of Geography and Regional Planning, Delta State University, Abraka (2011).

[11] B. L. Folsom, C. R. Lee, D. J. Bates. Influence of disposal environment on availability and plant uptake of heavy metals in dredged material. Technol. Rep. EL-81-12. US Army Corps of Engineers Waterways Experiment Station, Vicksburg, MS (1981).

[12] A. Walkley, I. A. Black. An examination of Degtjareff method for determining soil organic matter and proposed modification of the chronic acid and titration method. Soil Science. 37 (1934) 29-38.

[13] USEPA (United State Environmental Protection Agency). Methods for chemical analysis of water and wastes. 3rd Edition, Environmental Protection Agency, Environmental Monitoring Systems. Laboratory-Cincinnati (EMSL-Ci), Cincinnati, Ohio 45268, EPA-600/4-79-020, Method 413.1 (1983).

[14] IITA (International Institute of Tropical Agriculture). Selected methods for soil and plant analysis. IITA press, Ibadan, Nigeria. Manual Series. 1 (1984) 10-50.

[15] R. Lacatusu. Appraising levels of soil contamination and pollution with heavy metals. In: Land information system for planning the sustainable use of land resources. H. J. Heinike, W. Eckelman, A. J. Thomasson, R. J. A. Jones, L. Montanarella and B. Buckley (Eds.), European Communities, Luxembourg, pp: 393-402 (1998).

[16] DPR (Department of Petroleum Resources). Environment Guidelines and Standards for the Petroleum Industry in Nigeria (EGASPIN) Revised Edition (2002).

[17] P. S. Harikumar, U. P. Nasir and R. M. P. Mujeebu. Distribution of heavy metals in the core sediments of a tropical wetland system. International Journal of Environmental Science Technology. 6(2) (2009) 225-232.

[18] C. da Silveira Fiori, A. P. de Castro Rodrigues, R. E. Santelli, R. C. Cordeiro, R. G. Carvalheira, P. C. Araújo, Z. C. Castilhos, E. D. Bidone. Ecological risk index for aquatic pollution control: a case study of coastal water bodies from the Rio de Janeiro State, southeastern Brazil. Geochimica Brasiliensis. 27 (2013) 24-36.

[19] F. E. Okieimen. Heavy metals enrichment, distribution and availability in soils adjacent to anthropogenic point source: Wood treatment site in Benin City. Monograph by GeoEnvironmental and Climate change adaptation research centre, Benin City. pp 47 - 52 (2014).

[20] A. H. M. J. Al Obaidy, A. H. Talib, S. R. Zaki. Environmental assessment of heavy metal distribution in sediments of Tigris River within Baghdad City. International Journal of Advanced Research. 2 (2014) 947-952.

[21] Y. B. Yang, L. B. Sun. Status and control counter measures of heavy metal pollution in urban soil. Environmental Protection Science. 35(4) (2009) 79-81. 
[22] D. E. D. Kadem, O. Rached, A. Krika, Z. Gheribi-Aoulmi. Statistical analysis of vegetation incidence on contamination of soils by heavy metals $(\mathrm{Pb}, \mathrm{Ni}$ and $\mathrm{Zn})$ in the vicinity of an iron steel industrial plant in Algeria. Environmetrics. 15 (2004) 447-462.

[23] N. J. McKenzie, D. J. Jacquier, R. F. Isbell, K. L. Brown. Australian soils and landscapes: An illustrated compendium. CSIRO Publishing: Collingwood, Victoria (2004).

[24] K. Fujii, S. Funakawa, T. Kosaki. Soil acidification: Natural processes and human impact. Pedologist. 55 (2012) 415-425.

[25] M. Tomašić, Ț. Zgorelec, A. Jurišić, I. Kisić. Cation exchange capacity of dominant soil types in the Republic of Croatia. Journal of Central European Agriculture. 14 (2013) 937-951.

[26] G. Moore, P. Dolling, B. Porter, L. Leonard. Soil acidity. In soil guide. A handbook for understanding and managing agricultural soils. (Ed. G Moore) Agriculture Western Australia Bulletin No. 4343 (1998).

[27] A. A. Amusan, V. D. Ige, R. Oluwale. Characteristics of soils and crops uptake of metals in municipal waste dump in Nigeria. J. Hum. Ecol. 17 (2005) 167 -171.

[28] O. B. Ojuederie, O. O. Babalola. Microbial and plant-assisted bioremediation of heavy metal polluted environments: A Review. International Journal of Environmental Research and Public Health. 14 (2017) 1504-1530.

[29] J. H. Duffus. Heavy metals "a meaningless term" (IUPAC Technical Report). Pure Applied Chemistry. 74 (2002) 793807.

[30] B. A. Adelekan, K. D. Abegunde. Heavy metals contamination of soil and groundwater at automobile mechanic villages in Ibadan, Nigeria. International Journal of the Physical Sciences. 6(5) (2011) 1045-1058.

[31] A. E. Omotayo, O. Y. Ojo, O. O. Amund. Crude oil degradation by microorganisms in soil composts. Research Journal of Microbiology. 7 (2012) 209-218.
[32] L. Jarup. Hazards of heavy metal contamination. British Medical Bulletin. 68(1) (2003) 167-182.

[33] O. M. Adedokun, A. E. Ataga. Effect of amendment and bioaugumentation of soil polluted with crude oil automotive gasoline and mechanic waste on the growth of cowpea (Vigna unguiculata L. walp). Scientific Research. 2(5) (2007) 11471149 .

[34] D. E. Vwioko, G. O. Anoliefo, S. D. Fashemi. Metals concentration in plant tissues of Ricinus communis L. (Castor oil) grown in soil contaminated with spent lubricant oil. $J$. Appl. Sci. Environ. Mgt. 10 (2006) 127-134.

[35] S. Bello, Y. I. Zakari, I. G. E. Ibeanu, B. G. Muhammad. Evaluation of heavy metal pollution in soils of Dana Steel limited dumpsite, Katsina State, Nigeria using Pollution load and degree of contamination indices. American Journal of Engineering Research. 4 (12) (2015) 161-169.

[36] A. A. Adeniyi, J. A. Afolabi. Determination of total petroleum hydrocarbons and heavy metals in soils within the vicinity of facilities handling refined petroleum products in Lagos metropolis. Environ Int. 28(1-2) (2002) 79-82.

[37] L. F. Martins, R. S. Peixoto. Biodegradation of petroleum hydrocarbons in hypersaline environments. Braz. J. Microbiol. 43 (2012) 865-872.

[38] J. L. Reeves and M. A. Liebig. Depth matters: soil pH and dilution effects in the northern Great Plains. Soil Science Society of America Journal. 80 (2016) 1424-1427.

[39] N. K. Fageria and A. Moreira. The role of mineral nutrition on root growth of crop plants. Advances in Agronomy. 110 (2011) 251-331.

[40] N. K. Fageria, V. C. Baligar. Evaluation of tropical legume cover crops for copper use efficiency. American Journal of Plant Sciences. 5(9) (2014) 1236-1247. 